\title{
Beta-adrenergic Blockade in Hypertrophic Obstructive Cardiomyopathy
}

\author{
G. CHERIAN,* M.D. ; I. F. BROCKINGTON, $\dagger$ M.R.C.P. ; P. M. SHAH, $\ddagger$ M.D. ; \\ C. M. OAKLEY, $\S$ M.D., M.R.C.P.; J. F. GOODWIN,\| M.D., F.R.C.P.
}

Brit. med. F., 1966, 1, 895-898

Hypertrophic obstructive cardiomyopathy is a disorder of ventricular muscle characterized by asymmetrical hypertrophy and unusually rapid ventricular ejection of a normal stroke volume (Goodwin et al., 1960 ; Braunwald et al., 1964). The presence of a systolic gradient between the left ventricle and the aorta has been taken as evidence of obstruction of the ventricular outflow tract, but recent observations suggest that the pressure gradient may be due to continuing contraction in areas of the ventricle which have been completely emptied early in systole (Criley et al., 1965). The hypertrophy also leads to a restrictive effect with a high ventricular filling pressure. On clinical and haemodynamic grounds the presentation may be purely "obstructive," occasionally purely restrictive, or, more often, a mixed form with varying combinations of obstruction and restriction.

The pathogenesis of this disorder is not clear. The stimulus for the hypertrophy is not known, but, at least in the obstructive form, the disease may be partly self-perpetuating. Everson Pearse (1964) has shown that the degree of sympathetic innervation and noradrenaline content of resected portions of outflowtract muscle is far beyond the normal level. Many studies have shown that the haemodynamic abnormality may be influenced by pharmacological and physiological manœuvres (Braunwald and Ebert, 1962 ; Goodwin et al., 1964). Excitement and exercise increase the outflow gradient, and so do drugs which increase the contractile force of the heart (drugs with a positive inotropic action) such as isoprenaline or digitalis. Treatment of this condition has up till now been surgical and restricted to those with an outflow gradient. Though beta-adrenergic blockade has little effect on the dynamics at rest, its long-term use may be beneficial by decreasing or preventing the exacerbations resulting from surges of adrenergic stimulation (Goodwin et al., 1964 ; Harrison et al., 1964). The bradycardia and consequent increase in the diastolic volume of the heart may also be beneficial.

This paper deals with the acute and long-term effects of betaadrenergic blockade in patients with hypertrophic obstructive cardiomyopathy.

\section{Patients and Methods}

This study deals with the experience of 65 patients with hypertrophic obstructive cardiomyopathy investigated at Hammersmith Hospital and the Postgraduate Medical School, London. The diagnosis was established by right and left heart catheterization studies with pharmacological intervention, and by selective angiocardiography. The technique, methods, and criteria have been described in detail before (Cohen et al., 1964).

\footnotetext{
* Honorary Research Assistant, Department of Medicine, Hammersmith Hospital, Postgraduate Medical School of London. Supported by Hospital, Postgraduate Medical School of London.
a grant from the International Cardiology Foundation.

† Formerly House-physician, Department of Medicine, Hammersmith Hospital, Postgraduate Medical School of London.

¥ Formerly Honorary Research Assistant, Department of Medicine, Hammersmith Hospital, Postgraduate Medical School of London.

$\checkmark$ Lecturer in Medicine, Hammersmith Hospital, Postgraduate Medical School of London. Supported by the British Heart Foundation.

|| Professor of Clinical Cardiology, Consultant Physician, Hammersmith Hospital, Posigraduate Medical School of London.
}

The effect of beta-adrenergic blockade was evaluated from acute studies with 2-isopropylamino-1-(2-naphthyl) ethanol hydrochloride (pronethalol; Alderlin) or 1-isopropylamino-3-(1naphthyloxy)-2-propanol hydrochloride (propranolol ; Inderal) given as a single intravenous dose, and the long-term results from oral administration of propranolol. The acute studies were done in two parts. One during the course of cardiac catheterization, to study the effect on the outflow tract gradient, and on the ventricular end-diastolic pressure (Table I) on the gradient produced by the previous administration of isoprenaline (Table II), and on the gradient after an ectopic beat (Table III). The second acute study was conducted on an out-patient basis, to see the effects of beta-adrenergic blockade on effort tolerance to a standard exercise test and the response to the Valsalva manœuvre. It was monitored by phonocardiographic and often by pulse-contour studies (see Fig.). Propranolol was used in a dose of $0.15 \mathrm{mg}$. $/ \mathrm{kg}$. body-weight and pronethalol in a dose of $1-2 \mathrm{mg} . / \mathrm{kg}$. body-weight.

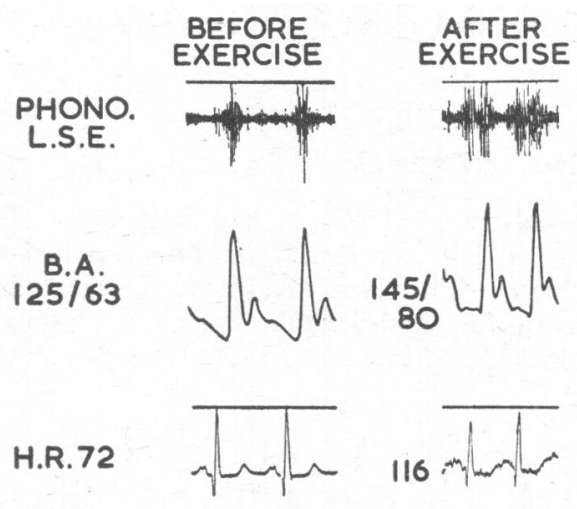

PROPRANOLOL

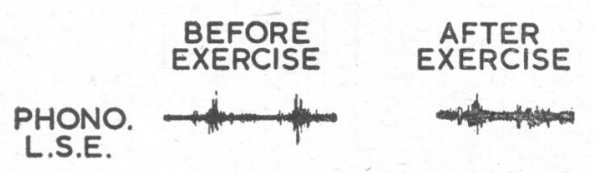

B.A.

$115 / 55$

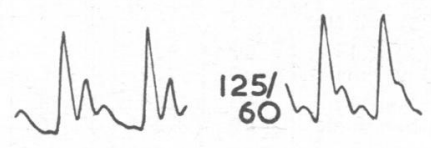

H.R. 64
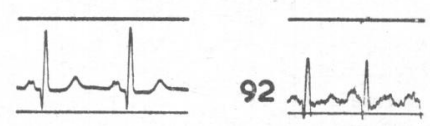

Phonocardiogram and brachial-artery pulse wave form before and after exercise. On the top is the control record. The murmur becomes louder and the abnormal systolic incisura in the arterial pulse wave louder after exercise. Below is the record after propranolo difference in the record taken while resting but after exercise the is little scarcely increased at all, and the pulse con murmur owing to near abolition of the abnormal systolic dip. PHONO normal = Ph to n.S.E. $=$ Phonocardiogram recorded at the left sternal edge. B.A.=Brachialartery pressure in $\mathrm{mm}$. Hg. H.R.=Heart rate/minute from the electrocardiogram. 
The long-term effects were evaluated in 13 patients followed up for 166 patient-months. There were nine males and four females in this group, and their ages ranged from 7 to 50 years. At periodic intervals these patients were evaluated in relation to their symptoms, and a detailed examination was done with particular reference to changes in the murmurs and heart sounds, and also in their response to a standard exercise test and Valsalva manœuvre. The study was not conducted as a doubleblind trial. The dose of propranolol varied from 5 to $20 \mathrm{mg}$. three times a day. During the latter stages of this study propantheline was added in a dose of $15 \mathrm{mg}$. three times a day to counteract the "unopposed" vagal effect.

\section{Results}

\section{Effect on Heart-rate and Blood-pressure}

There was always a fall in the resting heart-rate with betaadrenergic blockade in both the acute and long-term studies. The fall averaged 14 beats $/ \mathrm{min}$. in the acute and 17 beats $/ \mathrm{min}$. in the long-term studies. There was also a change in the response to a standard exercise test. Without beta-adrenergic blockade the average increase in heart-rate after exercise during the acute study was 40 beats/min., while after beta-adrenergic blockade the average rise was only 29 beats $/ \mathrm{min}$. In the longterm oral group of patients the average increase in heart-rate after exercise was only 16 beats $/ \mathrm{min}$.

The blood-pressure response was more variable. In the acute study there was an average fall of $10 \mathrm{~mm} . \mathrm{Hg}$ in three patients and an average rise of $13 \mathrm{~mm}$. $\mathrm{Hg}$ in six patients. After longterm oral administration there was an average fall of $18 \mathrm{~mm} . \mathrm{Hg}$ in eight patients and an average rise of $25 \mathrm{~mm}$. $\mathrm{Hg}$ in five patients.

\section{Effect on Cardiac Dynamics}

Acute beta-adrenergic blockade had little or no effect on the resting right or left ventricular outflow gradients in most patients (Table I). There was no significant change in the right or left ventricular end-diastolic pressure following betaadrenergic blockade. Similarly, the acute studies did not reveal

\begin{tabular}{|c|c|c|c|c|c|c|c|c|}
\hline \multicolumn{9}{|c|}{ TaBLE I } \\
\hline$\dot{\mathrm{z}}$ & 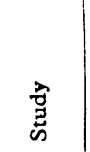 & 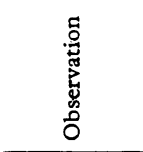 & 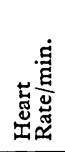 & 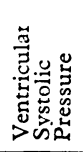 & 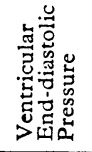 & 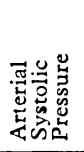 & 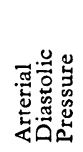 & 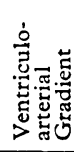 \\
\hline 1 & $\mathrm{LH}\{$ & $\begin{array}{l}\text { Control } \\
\text { Propranolol }\end{array}$ & $\begin{array}{l}72 \\
68\end{array}$ & $\begin{array}{l}130 \\
135\end{array}$ & $\begin{array}{l}23 \\
23\end{array}$ & $\begin{array}{l}115 \\
135\end{array}$ & $\begin{array}{l}53 \\
72\end{array}$ & $\begin{array}{r}15 \\
0\end{array}$ \\
\hline 2 & $\mathrm{LH}\{$ & $\begin{array}{l}\text { Control } \\
\text { Propranolol }\end{array}$ & $\begin{array}{r}100 \\
90\end{array}$ & $\begin{array}{l}190 \\
175\end{array}$ & $\begin{array}{c}25 \\
17-40\end{array}$ & $\begin{array}{l}125 \\
112\end{array}$ & $\begin{array}{l}75 \\
52\end{array}$ & $\begin{array}{l}65 \\
63\end{array}$ \\
\hline 3 & LH \{ & $\begin{array}{l}\text { Control } \\
\text { Propranolol }\end{array}$ & $\begin{array}{l}92 \\
68\end{array}$ & $\begin{array}{l}165 \\
165\end{array}$ & $\begin{array}{l}9-30 \\
4-23\end{array}$ & $\begin{array}{l}130 \\
124\end{array}$ & $\begin{array}{l}50 \\
57\end{array}$ & $\begin{array}{l}35 \\
41\end{array}$ \\
\hline 4 & LH \{ & $\begin{array}{l}\text { Control } \\
\text { Propranolol }\end{array}$ & $\begin{array}{l}84 \\
70\end{array}$ & $\begin{array}{l}142 \\
122\end{array}$ & $\begin{array}{l}10-25 \\
10-25\end{array}$ & $\begin{array}{r}92 \\
105\end{array}$ & $\begin{array}{l}48 \\
48\end{array}$ & $\begin{array}{l}50 \\
17\end{array}$ \\
\hline 5 & LH \{ & $\begin{array}{l}\text { Control } \\
\text { Pronethalol }\end{array}$ & $\begin{array}{l}92 \\
68\end{array}$ & $\begin{array}{l}170 \\
150\end{array}$ & $\begin{array}{l}15 \\
15\end{array}$ & $\begin{array}{l}160 \\
150\end{array}$ & $\begin{array}{l}70 \\
70\end{array}$ & $\begin{array}{r}10 \\
0\end{array}$ \\
\hline 6 & $\mathrm{LH}\{$ & $\begin{array}{l}\text { Control } \\
\text { Propranolol }\end{array}$ & $\begin{array}{l}90 \\
80\end{array}$ & $\begin{array}{l}180 \\
165\end{array}$ & $\begin{array}{l}15-30 \\
15-30\end{array}$ & $\begin{array}{l}115 \\
110\end{array}$ & $\begin{array}{l}60 \\
65\end{array}$ & $\begin{array}{l}65 \\
55\end{array}$ \\
\hline 7 & $\mathrm{LH}\{$ & $\begin{array}{l}\text { Control } \\
\text { Propranolol }\end{array}$ & $\begin{array}{l}77 \\
66\end{array}$ & $\begin{array}{l}125 \\
125\end{array}$ & $\begin{array}{r}5 \\
10\end{array}$ & $\begin{array}{l}115 \\
120\end{array}$ & $\begin{array}{l}65 \\
70\end{array}$ & $\begin{array}{r}10 \\
5\end{array}$ \\
\hline 8 & $\mathrm{LH}\{$ & $\begin{array}{l}\text { Control } \\
\text { Propranolol }\end{array}$ & $\begin{array}{l}75 \\
66\end{array}$ & $\begin{array}{l}175 \\
170\end{array}$ & $\begin{array}{l}10 \\
12\end{array}$ & $\begin{array}{l}95 \\
95\end{array}$ & $\begin{array}{l}60 \\
57\end{array}$ & $\begin{array}{l}80 \\
75\end{array}$ \\
\hline 9 & $\mathrm{RH}\{$ & $\begin{array}{l}\text { Control } \\
\text { Pronethalol }\end{array}$ & $\begin{array}{l}85 \\
80\end{array}$ & $\begin{array}{l}59 \\
55\end{array}$ & $\begin{array}{l}6 \\
6\end{array}$ & $\begin{array}{l}36 \\
36\end{array}$ & $\begin{array}{l}17 \\
24\end{array}$ & $\begin{array}{l}23 \\
19\end{array}$ \\
\hline 10 & RH \{ & $\begin{array}{l}\text { Control } \\
\text { Pronethalol }\end{array}$ & $\begin{array}{l}97 \\
88\end{array}$ & $\begin{array}{l}36 \\
36\end{array}$ & $\begin{array}{l}2 \\
4\end{array}$ & $\begin{array}{l}31 \\
34\end{array}$ & $\begin{array}{l}14 \\
16\end{array}$ & $\begin{array}{l}5 \\
2\end{array}$ \\
\hline 11 & $\mathrm{RH}\{$ & $\begin{array}{l}\text { Control } \\
\text { Propranolol }\end{array}$ & $\begin{array}{r}110 \\
84\end{array}$ & $\begin{array}{l}57 \\
46\end{array}$ & $\begin{array}{l}12 \\
10\end{array}$ & $\begin{array}{l}34 \\
30\end{array}$ & $\begin{array}{l}21 \\
15\end{array}$ & $\begin{array}{l}23 \\
16\end{array}$ \\
\hline 12 & $\mathrm{RH}\{$ & $\begin{array}{l}\text { Control } \\
\text { Propranolol }\end{array}$ & $\begin{array}{r}100 \\
80\end{array}$ & $\begin{array}{l}62 \\
53\end{array}$ & $\begin{array}{r}15 \\
7\end{array}$ & $\begin{array}{l}51 \\
45\end{array}$ & $\begin{array}{l}23 \\
14\end{array}$ & $\begin{array}{r}11 \\
8\end{array}$ \\
\hline 13 & $\mathrm{RH}\{$ & $\begin{array}{l}\text { Control } \\
\text { Propranolol }\end{array}$ & $\begin{array}{l}72 \\
64\end{array}$ & $\begin{array}{l}34 \\
34\end{array}$ & $\begin{array}{l}4 \\
5\end{array}$ & $\begin{array}{l}20 \\
20\end{array}$ & $\begin{array}{l}11 \\
11\end{array}$ & $\begin{array}{l}14 \\
14\end{array}$ \\
\hline 14 & $\mathrm{RH}\{$ & $\begin{array}{l}\text { Control } \\
\text { Pronethalol }\end{array}$ & $\begin{array}{r}100 \\
80\end{array}$ & $\begin{array}{l}62 \\
53\end{array}$ & $\begin{array}{r}15 \\
7\end{array}$ & $\begin{array}{l}51 \\
45\end{array}$ & $\begin{array}{l}23 \\
14\end{array}$ & $\begin{array}{r}11 \\
8\end{array}$ \\
\hline
\end{tabular}

any change in the intensity of the murmur at rest in six instances and resulted in a decrease in only two cases.

Exercise tests after acute beta-adrenergic blockade were not done routinely during cardiac catheterization. However, the results of adrenergic stimulation in the form of an isoprenaline infusion was tried. This produced an increase in the outflow gradient. These results could be prevented or diminished by beta-adrenergic blockade (Table II). Phonocardiographic studies were done on six patients before and after exercise, with and without acute beta-adrenergic blockade. All the cases showed an increase in the intensity of the murmur after exercise without beta-adrenergic blockade. After beta-adrenergic blockade, however, there was a decrease in two, and the increase in intensity of the murmur was less in the remaining four cases when compared with the control period. An example is shown (see Fig.).

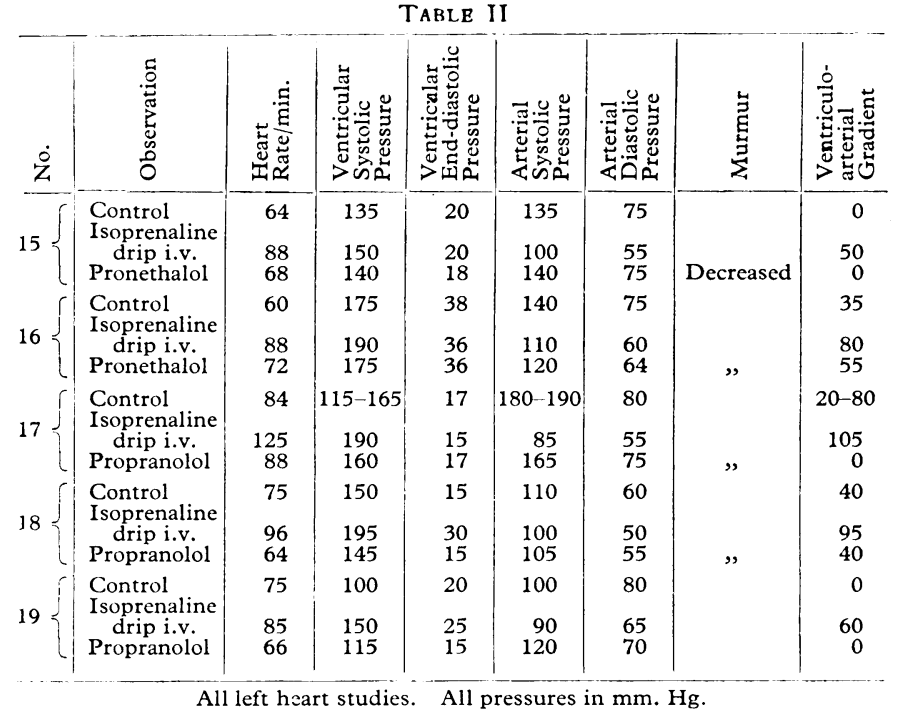

The response to the Valsalva manœuvre before betaadrenergic blockade was characterized by an increase in the outflow gradient during the period of peak strain due to a progressive fall (after a transient initial rise) in the arterial systolic pressure, while the left ventricular systolic pressure remained the same or even increased. The abnormal Valsalva response showed no significant change following acute betaadrenergic blockade, and the findings have been reported earlier (Shah et al., 1965b). However, an abnormal Valsalva response, as indicated by an increase in the intensity of the murmur, could be elicited in only two out of the six patients who had been on a long-term treatment.

The characteristic decrease in pulse pressure in the beat following a premature ventricular beat in patients with hypertrophic obstructive cardiomyopathy has been shown by Brockenbrough et al. (1961). The increase in outflow tract gradient and decrease in effective orifice size in the postpremature beat has also been documented by Braunwald et al. (1964). After beta-adrenergic blockade premature beats were fewer and the post-premature beat response was less predictable (Table III).

\section{Effects of Long-term Oral Treatment with Propranolol}

Of the 13 patients four had only outflow " obstruction," two had only inflow obstruction, and seven had combined outflow and inflow obstruction.

\section{Symptoms}

Effort intolerance was present in nine patients. Of these it improved in seven and was unchanged in one patient who had 
only outflow obstruction. Two patients were worse, one of whom had discontinued therapy and the other was on an inadequate dosage, as judged by the heart-rate. Syncope or faintness on effort was present in six patients: it disappeared in five, but was unchanged in one patient who was on an inadequate dosage. Angina on effort was present before therapy in two patients, in both of whom it disappeared with treatment. Nocturnal dyspnoea was present in three patients: it disappeared in one, remained the same in another, and appeared during inadequate therapy in the third. Fatigue was a common complaint and was present in nine patients: it disappeared in eight with treatment.

\begin{tabular}{|c|c|c|c|c|c|c|}
\hline \multicolumn{7}{|c|}{ TABLE III } \\
\hline No. & Observation & $\begin{array}{l}\text { Ventricular } \\
\text { Systolic } \\
\text { Pressure }\end{array}$ & $\begin{array}{c}\text { Ventricular } \\
\text { End-diastolic } \\
\text { Pressure }\end{array}$ & $\begin{array}{c}\text { Arterial } \\
\text { Systolic } \\
\text { Pressure }\end{array}$ & $\begin{array}{l}\text { Arterial } \\
\text { Diastolic } \\
\text { Pressure }\end{array}$ & $\begin{array}{c}\text { Ventriculo- } \\
\text { arterial } \\
\text { Gradient }\end{array}$ \\
\hline \multirow[t]{2}{*}{20} & \multirow{2}{*}{$\begin{array}{l}\text { Control } \\
\text { VPB } \\
\text { Control } \\
\text { VPB after B } \\
\text { blockade }\end{array}$} & $\begin{array}{l}165 \\
200 \\
165\end{array}$ & $\begin{array}{c}10-20 \\
18 \\
10-20\end{array}$ & $\begin{array}{l}124 \\
115 \\
125\end{array}$ & $\begin{array}{l}63 \\
60 \\
65\end{array}$ & $\begin{array}{l}41 \\
85 \\
40\end{array}$ \\
\hline & & 180 & 18 & 140 & 80 & 40 \\
\hline \multirow{2}{*}{21} & \multirow{2}{*}{$\begin{array}{l}\text { Control } \\
\text { VPB } \\
\text { Control } \\
\text { VPB after B } \\
\text { blockade }\end{array}$} & $\begin{array}{l}225 \\
275 \\
220\end{array}$ & $\begin{array}{l}0-12 \\
12 \\
0-10\end{array}$ & $\begin{array}{l}220 \\
180 \\
215\end{array}$ & $\begin{array}{l}150 \\
120 \\
140\end{array}$ & $\begin{array}{r}5 \\
95 \\
5\end{array}$ \\
\hline & & 280 & 10 & 185 & 110 & 95 \\
\hline \multirow{3}{*}{22} & \multirow{3}{*}{$\begin{array}{l}\text { Control } \\
\text { VPB } \\
\text { Control } \\
\text { VPB after B } \\
\text { blockade }\end{array}$} & 165 & 13 & 100 & 62 & 65 \\
\hline & & $\begin{array}{l}220 \\
170\end{array}$ & $\begin{array}{l}12 \\
10\end{array}$ & $\begin{array}{r}75 \\
100\end{array}$ & $\begin{array}{l}50 \\
65\end{array}$ & $\begin{array}{r}145 \\
70\end{array}$ \\
\hline & & 200 & 10 & 76 & 48 & 124 \\
\hline \multirow[t]{2}{*}{23} & \multirow{2}{*}{$\begin{array}{l}\text { Control } \\
\text { VPB } \\
\text { Control } \\
\text { VPB after B } \\
\text { blockade }\end{array}$} & $\begin{array}{l}150 \\
185 \\
150\end{array}$ & $\begin{array}{l}5 \\
5 \\
5\end{array}$ & $\begin{array}{r}100 \\
80 \\
100\end{array}$ & $\begin{array}{l}50 \\
40 \\
50\end{array}$ & $\begin{array}{r}50 \\
105 \\
50\end{array}$ \\
\hline & & 184 & 4 & 82 & 40 & 102 \\
\hline \multirow[t]{2}{*}{24} & \multirow{2}{*}{$\begin{array}{l}\text { Control } \\
\text { VPB } \\
\text { Control } \\
\text { VPB after B } \\
\text { blockade }\end{array}$} & $\begin{array}{l}180 \\
200 \\
165\end{array}$ & $\begin{array}{l}15-30 \\
15-30 \\
15-25\end{array}$ & $\begin{array}{r}115 \\
90 \\
115\end{array}$ & $\begin{array}{l}60 \\
55 \\
62\end{array}$ & $\begin{array}{r}65 \\
110 \\
50\end{array}$ \\
\hline & & 190 & $15-30$ & 90 & 45 & 100 \\
\hline \multirow[t]{2}{*}{25} & \multirow{2}{*}{$\begin{array}{l}\text { Control } \\
\text { VPB } \\
\text { Control } \\
\text { VPB after B } \\
\text { blockade }\end{array}$} & $\begin{array}{l}68 \\
80 \\
70\end{array}$ & $\begin{array}{l}10 \\
12 \\
10\end{array}$ & $\begin{array}{l}53 \\
44 \\
55\end{array}$ & $\begin{array}{l}18 \\
12 \\
20\end{array}$ & $\begin{array}{l}15 \\
36 \\
15\end{array}$ \\
\hline & & 70 & 10 & 54 & 20 & 16 \\
\hline \multirow[t]{2}{*}{26} & \multirow{2}{*}{$\begin{array}{l}\text { Control } \\
\text { VPB } \\
\text { Control } \\
\text { VPB after B } \\
\text { blockade }\end{array}$} & $\begin{array}{l}140 \\
180 \\
140\end{array}$ & $\begin{array}{l}0-5 \\
0-5 \\
0-5\end{array}$ & $\begin{array}{l}135 \\
125 \\
130\end{array}$ & $\begin{array}{l}95 \\
65 \\
90\end{array}$ & $\begin{array}{r}5 \\
55 \\
10\end{array}$ \\
\hline & & 165 & $0-5$ & 125 & 70 & 40 \\
\hline
\end{tabular}

All pressures in mm. Hg. No. 6 was a right heart study. The others were all left heart studies.
$\mathrm{VPB}=$ The beat following a ventricular premature beat.

\section{Signs}

A jerky pulse appreciated at the bedside was present in all 13 patients and remained so in 10 of them after treatment. A third heart sound was present in nine and remained so in all nine. A fourth heart sound was present in 11 patients and disappeared in only one of them during therapy. The second sound was paradoxically split in four patients before treatment but became normal in three of them after treatment. All the 13 patients had an ejection type of systolic murmur. After treatment the intensity of the murmur decreased in nine and remained the same in four. A systolic thrill accompanied the murmur in four patients and disappeared in three after therapy. The post-exercise increase in the intensity of the murmur was present in only 4 out of 11 patients after treatment. The postValsalva strain increase in the intensity of the murmur could be elicited in only two out of six patients who had been on therapy.

\section{Radiological Features}

During treatment the heart increased in size in 10 out of 13 patients, remained the same in two, and decreased in one. Pulmonary venous congestion was present in 10 patients; it remained unchanged in eight and decreased slightly in two.
There was no significant change in the size of the left atrium after treatment.

\section{Electrocardiogram}

There was no significant change in the electrocardiogram after treatment with propranolol. Ventricular premature complexes were present in four patients before treatment, but persisted in only one of them after treatment.

\section{Discussion}

The surgical treatment of patients with hypertrophic obstructive cardiomyopathy has been restricted to those with serious symptoms such as angina and/or syncope with a demonstrable outflow tract gradient at rest or on provocation with isoprenaline. The objective changes at post-operative cardiac catheterization have not always paralleled the subjective improvement (Bentall et al., 1965). This is not surprising in view of the unique haemodynamic fault in this condition. The unduly rapid and excessive ventricular emptying may result in the recording of an outflow gradient whose exact height is perhaps incidental rather than a direct expression of the severity of the basic fault. In addition, recent observations by Morrow et al. (1965) would suggest that, in dogs, outflow tract gradients may result from the position of the catheter tip within clefts between hypertrophied trabeculae rather than from true outflow tract obstruction.

Most patients with hypertrophic obstructive cardiomyopathy have varying combinations of "obstruction" to ventricular outflow and inflow. If outflow obstruction is trivial and obstruction to inflow is the main problem then surgical treatment has not been recommended. In certain patients there may be a gradual transition from outflow to inflow obstruction (Goodwin et al., 1960).

There is little doubt now that hypertrophic obstructive cardiomyopathy is a disease of ventricular muscle. Everson Pearse (1964) has shown conclusively that the sympathetic innervation and noradrenaline content of resected outflow tract muscle of patients with hypertrophic obstructive cardiomyopathy is far beyond the normal level. Whether this represents the only important derangement is not quite clear. Patients with muscular outflow tract obstruction secondary to aorticvalve stenosis and those with discrete subvalvar aortic stenosis have not shown similar changes. This would suggest that these changes represent a primary abnormality in hypertrophic obstructive cardiomyopathy. The increase in outflow tract gradient with excitement, apprehension, exercise, and isoprenaline infusion would suggest that surges of adrenergic stimulation could exaggerate the excessive ejection and augment the outflow tract obstruction.

Our studies have shown that beta-adrenergic blockade has little or no effect on the haemodynamics of hypertrophic obstructive cardiomyopathy at rest, and so lack of improvement in objective signs during the follow-up is not surprising. The acute studies, however, show that beta-adrenergic blockade is effective in decreasing or abolishing the increase in dynamic obstruction that results from exercise or isoprenaline infusion. It is possible that repetitive sympathetic stimulation might perpetuate the condition, and, if these surges of sympathetic stimulation during normal exercise and emotion are prevented, there may be regression in course of time.

The response to the Valsalva manœuvre has shown slight variations between the acute and long-term studies with betaadrenergic blockade. In the acute studies beta-adrenergic blockade did not prevent the increase in outflow gradient thit occurs in hypertrophic obstructive cardiomyopathy during the strain period. During the long-term studies indirect phonocardiographic evidence suggests that, at least in some cases, this; 
increase in gradient did not occur. The response in the nontreated hypertrophic obstructive cardiomyopathy is presumably due to a combination of diminishing ventricular volume and sympathetic stimulation as a result of the decreasing pulse pressure. The reasons for the variation between the acute and long-term studies is not clear. This may be related to the increase in heart size and ventricular volume as a result of longterm drug treatment. This baseline increase in ventricular volume probably compensates for the decreasing left ventricular volume during the strain period.

The characteristic increase in outflow gradient with an increase in the intensity of the murmur and decrease in arterial pulse pressure in the post-ectopic beat is probably due in part to post-extrasystolic potentiation, resulting in a more vigorous contraction (Hoffman et al., 1956). The response following beta-adrenergic blockade was more variable, and there was no increase in outflow gradient in some patients.

The importance of ventricular volume in hypertrophic obstructive cardiomyopathy has been emphasized in previous studies (Shah et al., 1965a). The outflow tract gradient can be induced or increased by venesection and decreased or abolished by reinfusion. This effect persists after beta-adrenergic blockade. An increase in heart size was seen in 9 out of the 13 patients, and this has also been the experience of other workers (Chamberlain, 1965). Some of the improvement in the patients with hypertrophic obstructive cardiomyopathy following beta-adrenergic blockade may be due to increase in ventricular volume.

Subjective improvement, including relief from breathlessness or syncope or angina, was found in 10 out of the 13 patients on long-term treatment. The mechanism of syncope on effort in these patients is not clear, and the improvement may partly be related to the effect of the drug on ventricular arrhythmias. It is interesting that angina of effort improved on doses which are less than those effective in patients with arteriosclerotic heart disease. Though objective signs of improvement were few, a paradoxical split of the second heart sound became normal in three out of the four patients who had this sign, suggesting improved left ventricular function. Braunwald et al. (1964) have shown that there is a correlation between the intensity of the systolic murmur and the outflow gradient. The intensity of the murmur decreased in 9 out of the 13 patients. At the same time the characteristic post-exercise increase in the intensity of the murmur was no longer present in 7 out of 11 patients in whom this was tested. Also, there was no postValsalva increase in the murmur in four out of six patients in whom this test was done after treatment. These findings, though not conclusive, would suggest that beta-adrenergic blockade is of some value in the long-term treatment of patients with hypertrophic obstructive cardiomyopathy. It is appropriate to emphasize the fact that propranolol is a very powerful drug which can induce heart failure. In patients with more conventional heart disease or with cardiomyopathies of congestive type a heightened sympathetic drive may be vital and its removal may precipitate severe heart failure or even death.
Such patients, moreover, are unduly sensitive to the drug, and even small doses may be dangerous. It is therefore imperative to establish the exact diagnosis by full haemodynamic and angiographic study before embarking on treatment by betaadrenergic blockade.

\section{Summary}

This paper deals with our experience with beta-adrenergic blockade in patients with hypertrophic obstructive cardiomyopathy investigated at the Hammersmith Hospital and Postgraduate Medical School. Acute studies showed little or no effect on resting gradients. Beta-adrenergic blockade was, however, effective in decreasing or abolishing the increase in outflow gradient resulting from exercise or isoprenaline infusion. Long-term studies in 13 patients showed subjective improvement in 10 . Objective signs did not always parallel the improvement, though there was often a decrease in the intensity of the murmur due to an increase in heart size.

This is a preliminary report, and suggests that betaadrenergic blockade may be of value in the long-term management of patients with hypertrophic obstructive cardiomyopathy. Longer studies in a larger group of patients are indicated before any firm conclusions can be drawn. A warning note is sounded concerning the importance of establishing a firm diagnosis before embarking on treatment.

\section{REFERENCES}

Bentall, H. H., Cleland, W. P., Oakley, C. M., Shah, P. M., Steiner, R. E., and Goodwin, J. F.'(1965). 'Brit. Heart F., 27, 585.

Braunwald, E., and Ebert, P. A. (1962). Amer F. Cardiol., 10, 489.

- Lambrew, C. T., Rockoff, S. D., Ross, J., jun., and Morrow, A. G (1964). American Heart Association Monogr. No. 10. American Heart Ass., New York.

Brockenbrough, E. C., Braunwald, E., and Morrow, A. G. (1961) Circulation, 23, 189.

Chamberlain, D. A. (1965). Symposium on Propranolol, I.C.I.

Cohen, J., Effat, H., Goodwin, J. F., Oakley, C. M., and Steiner, R. E. (1964). Brit. Heart f., 26, 16.

Criley, J. M., Lewis, K. B., White, R. I., jun., and Ross, R. S. (1965). Circulation, 32, 881 .

Goodwin, J. F., Hollman, A., Cleland, W. P., and Teare, D. (1960). Brit. Heart f., 22, 403.

Shah, P. M., Oakley, C. M., Cohen, J., Yipintsoi, T., and Pocock, W. (1964). Ciba Foundation Symposium on Cardiomyopathies, p. 189.

Harrison, D. C., Braunwald, E., Glick, G., Mason, D. T., Chidsey, C. A., and Ross, J., jun. (1964). Circulation, 29, 84.

Hoffman, B. F., Bindler, E., and Suckling, E. E. (1956). Amer. $\mathcal{F}$. Physiol., 185, 95

Morrow, A. G., Vasko, J. S., Henney, R. P., and Brawley, R. K. (1965). Amer. F. Cardiol., 16, 540.

Pearse, A. G. E. (1964). Ciba Foundation Symposium on Cardiomyopathies, p. 132.

Shah, P. M., Amarasingham, R., and Oakley, C. M. (1965a). Brit. Heart f., 27,83 .

- Yipintsoi, T., Amarasingham, R., and Oakley, C. M. (1965b). Amer. F. Cardiol., 15, 793. 